\title{
Discussion on the Integration Strategy of Industry and Education of Finance and Economics Specialty in University
}

\author{
Dejun Zou ${ }^{1,2, *}$
}

\author{
${ }^{1}$ School of Literature, Jinan University, Guangdong, China \\ ${ }^{2}$ Guangdong Polytechnic of Industry and commerce, Guangdong, China \\ *Corresponding author. Email: zoudejun2011@126.com
}

\begin{abstract}
Industry university research cooperation is one of the difficulties in the training of economic and management professionals in Colleges and universities, which shows that teachers do not master the latest technology and teaching materials, lagging the industrial scene. Teachers and teaching materials are the key obstacles to the cooperation of production, teaching and research of economic management majors in Colleges and universities. The path of industry university research cooperation of economic management specialty in Colleges and universities should start from the construction of a structured teaching team between colleges and enterprises. Through the curriculum teaching reform, the teaching process and industrial work process should be combined in a more flexible way, and the classroom teaching should be combined with the second classroom and student community activities, so as to introduce the latest technology and industrial scenarios and materials into the curriculum teaching Finally, improve the quality of economic management professional training.
\end{abstract}

Keywords: Industry university research cooperation, Finance, Team, Curriculum.

\section{THE DIFFICULTIES OF INDUSTRY UNIVERSITY RESEARCH COOPERATION IN ECONOMIC MANAGEMENT SPECIALTY OF COLLEGES AND UNIVERSITIES}

Industry university research cooperation is an important method to solve the problem that talent training is separated from industrial development. Xing Hui and others believe that industry university research cooperation is a cooperative activity and relationship of complementary resource advantages between education and industry in order to promote the cultivation and development of skills. The industry corresponding to the industry university research cooperation of economic management specialty in Colleges and universities is finance and economics industry. With the wide application of intelligent devices, the demand of financial industry for talents' technical skills has also changed. The financial industry's demand for skilled personnel with basic repetitive operations has gradually decreased, such as cashier, accounts receivable and payable check, reimbursement form and other original documents filling and auditing. On the contrary, with the wide application of intelligent equipment, the demand for skilled personnel such as data collection and collation, equipment maintenance, financial data analysis and collation will continue to grow. Taking accounting as an example, financial robot will replace human to work in financial accounting and other related work, while collecting, sorting and analysing information related to operation and management decision must be completed by man-machine combination. In short, a lot of heavy work is undertaken by intelligent equipment, which can obtain high efficiency and low error.

The combination of human and computer, the use and maintenance of intelligent equipment and other jobs are the post skills required by the financial industry for talents. But at present, these intelligent technologies and equipment are still the latest industrial technology and equipment, often involving trade secrets. It is difficult for teachers majoring in economics and management in Colleges and universities to access these intelligent devices and technologies and to introduce them into the teaching process. Because the teachers of economics and 
management major in Colleges and universities are not clear about these intelligent devices and technologies, it is difficult to organize and connect the teaching materials and scenarios of these intelligent devices and technologies. In the absence of teachers who master the new technology and equipment, as well as the lack of teaching materials and scenarios that meet the needs of the industry, it is difficult for colleges and universities to cultivate technical talents suitable for the needs of industrial development. The teaching of economics and management majors in Colleges and universities urgently needs to obtain the latest technical data and scenarios in the practice of financial industry. However, enterprises in the financial industry need to maintain their leading position in financial technology, and they do not want to share it with other enterprises or colleges and universities. Because the economic management professional teaching team in Colleges and universities obtains these technologies, the talents trained by them are likely to work in the enterprises of competitors. Only after enterprises obtain enough talents or other benefits can they share the latest technical information with colleges and universities.

From the process of industry university research cooperation of economic management majors in Colleges and universities, both sides of colleges and enterprises should be able to get reports from the cooperation. As a profit-making economic organization, the goal of any economic activity is to obtain profits. In our country, most colleges, and universities, as institutions undertaking the national education function, take the cultivation of talents, scientific research, social service, and cultural inheritance as the main goal, and do not take economic interests as the main goal. This provides enough space for school enterprise cooperation. However, as far as the industry university research cooperation of economic management majors in Colleges and universities is concerned, restricted by business secrets and other factors, the practice opportunities that teachers of economic management majors in Colleges and universities get from the industry university research cooperation are often not the latest financial and economic industrial technology work, but relatively mature financial and economic technical skills practice. From the perspective of enterprises, teachers and students of colleges and universities come to enterprises for practical training in order to learn the latest technology of enterprises, rather than help enterprises develop new technology. The gap between enterprises and universities in industrial technology is growing in the process of rapid industrial upgrading. Since colleges and universities are unable to give enterprises technical support, and enterprises are also difficult to obtain direct economic benefits from colleges and universities, it is difficult for colleges and universities to achieve the goal of complementary advantages of resources between colleges and enterprises.

\section{THE REASONS FOR THE DIFFICULTIES IN THE COOPERATION OF PRODUCTION, TEACHING AND RESEARCH IN THE ECONOMIC MANAGEMENT SPECIALTY OF COLLEGES AND UNIVERSITIES}

The main reasons why teachers have become the difficulties of industry university research cooperation of economic management majors in Colleges and universities are as follows: first, the latest technology of financial industry involves trade secrets. Financial industry related work involves funds. Fund related work is a very sensitive department and business for many industries and enterprises. Through the analysis of an enterprise's capital situation, we can reveal the trade secrets, such as the enterprise's purchase fund flow, which can reflect the important material supply status and other important business information. Second, the social atmosphere does not encourage teachers to participate in the financial and technical work of enterprises and enterprises to participate in the work of vocational colleges. Although the state has issued a system to encourage the professional and technical personnel of administrative institutions to work part-time and parttime in the enterprise industry, for example, the Ministry of human resources and social security has issued the "guidance on supporting and encouraging the innovation and Entrepreneurship of professional and technical personnel in public institutions", but there has not yet formed a social atmosphere to encourage teachers of higher schools to engage in economic management professional and technical work in industrial enterprises.

The main reasons why teaching materials become the difficulties of industry university research cooperation of economic management majors in Colleges and universities are as follows: firstly, the intelligent development of financial industry is far faster than the teaching content of economic management specialty, and colleges and universities and teachers do not timely grasp the technical trends of the industry. As mentioned above, colleges and universities and teachers are trapped in the daily teaching of colleges and universities, so it is difficult to transform the latest technology of financial industry into teaching content, or even contact with the latest technology of financial industry. Secondly, The scale of students majoring in economics and management in Colleges and universities is huge, which needs a lot of industrial practice technology teaching environment and materials. The intelligent environment, equipment and technical data of financial industry are all in the latest state, and the price is very expensive. Most colleges and universities lack sufficient funds to develop or purchase these teaching materials related to the latest financial industry technology. 


\section{THE STRATEGY OF INDUSTRY UNIVERSITY RESEARCH COOPERATION OF ECONOMIC MANAGEMENT SPECIALTY IN COLLEGES AND UNIVERSITIES}

To sum up, there are two obstacles to the cooperation between teachers and teaching materials in the economic management specialty of colleges and universities. The root causes are not only the social system atmosphere, but also the individual understanding and working methods of school teachers. Therefore, in order to break through these two difficulties, we need to systematically consider many factors such as technological progress, curriculum reform, teacher team and teaching organization management.

\subsection{Taking the Future Industrial Technology as the Teaching Design Orientation}

From the perspective of the process that the role of students majoring in economics and management in Colleges and universities can achieve employment and life in the future through vocational education, students need to master the "future technology" that they need as future professionals and social people. Students majoring in economics and management are in the critical environment of entering society when they enter colleges and universities. If the teaching design of economics and management majors in Colleges and universities only focuses on the current technical skills of economics and management majors, or even only on the process, rather than the future technical skills, it will be difficult for colleges and universities to endow students with future industrial technology. It is difficult to imagine that talents who are suitable for the development of industrial technology in the future can be cultivated in the education and teaching system which is not systematically oriented to the future social life. For the future professional talent demand of economic and management majors, colleges and universities need to carry out teaching design according to the development trend of financial industry and technology in the next 3-10 years. In the course teaching reform, it is clearly required to arrange a certain period to carry out the teaching activities of the development trend of the professional technical skills contained in the course in the next 3-10 years. In the form, students can take the initiative to carry out social survey Research, to the industry enterprise technology experience, access to technical skills literature and so on, and during performance evaluation to reflect the future professional technical skills examination. The future industrial technology-oriented curriculum teaching design focuses on the establishment of future oriented vocational and social personnel training system of technical skills. The relationship is as follows: "curriculum teaching design for future technical skills of financial industry $=$ curriculum teaching based on existing financial industry + future technical skills development trend of financial industry in 3-10 years".

\subsection{Set up Structured Teaching Team Based on Curriculum Teaching Reform}

After clarifying the future financial industry technology-oriented curriculum teaching design, it is necessary to establish a structured teaching team based on the curriculum teaching reform. Through the training of technical and skilled personnel for the future development of the financial industry as the interest link point, attract the industry enterprise personnel to participate in the specific curriculum teaching reform. The school's teachers engaged in the teaching of Finance and economics courses and the technical staff engaged in financial industry in industrial enterprises take the technical development and personnel training of financial and economic industries of common interest as the cooperative objects. In the scope of curriculum teaching reform project, the school and enterprise cooperate closely and employ each other's personnel, so that teachers can undertake specific technical posts or part of technical work of enterprises Enterprise experts undertake part of the teaching tasks and professional construction of skills courses, so as to form a stable structured teaching team for future financial and industrial technology courses. In principle, the structured teacher team of course teaching is allocated according to the ratio of 1:1 between industry enterprises and teachers, and the specific practical technology courses can even reach 2:1. The enterprise experts in the structured teaching team sign the technical teaching labor contract with the school, and the teachers in the structured teaching team also need to sign the technical consulting service contract with the enterprise. In this way, teachers have the status of enterprise employees, and enterprise experts also assume the role of teachers. Both the school and the enterprise assess the employees of the other party according to the part-time labor contract. Generally speaking, the work that the structured teaching team needs to complete includes but is not limited to: first, to jointly undertake the financial and economic technical services of enterprises and industries; second, to jointly carry out financial policy research and technical research; third, to jointly develop and design the specific teaching content of corresponding skill courses, and even reconstruct the skill curriculum system to promote the teaching objectives, work objectives and teaching contents The integration of teaching content and work content, teaching method and work method, teaching evaluation and work evaluation can realize the integration of teaching content and industrial development. 


\subsection{Teaching Reform Mode}

On the basis of establishing a long-term and stable structured teaching team, under the guidance of the curriculum teaching reform oriented to the future financial industry technology, both the school and the enterprise fully mobilize the enthusiasm of both the school and the enterprise in the course structured teaching team, so as to continuously improve the skills The course teaching brings in the technology research and development and social services of financial and economic industries, and constantly brings the latest industrial technology into the course teaching: Based on the course teaching reform, the course teaching team connects with the experts of financial and economic industries and enterprises externally, and connects with the members of students' Professional associations internally, such as the members of students' associations such as the special accounting society and ERP society on campus. In the specific technology research and development, curriculum teaching resources construction and teaching activities, enterprise experts in specific industries, school teachers and students' Professional Association members form a close cooperation team of technical services + curriculum construction services + teaching services, to integrate teaching activities and technical work. Teachers and students are familiar with financial work situations and materials and master them when participating in enterprise practice New technology of Finance and economics, enterprise experts accumulate teaching experience and methods in the process of participating in teaching, and jointly develop curriculum teaching resources for future financial industry technology. In this way, teaching activities can integrate the "first classroom" and "second classroom" of course teaching. Meanwhile, technical service activities can form the "two classes and one meeting" course teaching reform mode, give full play to the advantages of industry university research cooperation of structured teaching team, and form teaching chain, industry chain, and enterprise cooperation The integration of interest chain, the establishment of a long-term mechanism of school enterprise cooperation to cultivate economic management professionals, teachers actively establish a close docking relationship with enterprise experts, give play to the guiding role of industry and enterprise technology and management personnel on the construction of curriculum resources, and improve the quality of curriculum teaching, so as to better realize the industry university research cooperation of economic management specialty.

\section{CONCLUSION}

Under the environment of encouraging vocational education by the state, the financial and economic industry's own characteristics and the actual situation of economic and management majors in Colleges and universities, the strategy of financial integration should be to carry out curriculum teaching design for future technology, establish a long-term stable structured team, and stimulate teachers and enterprise experts to be active through part-time labour contract We should carry out the curriculum teaching reform that integrates the first classroom, the second classroom and the members of student associations, promote the teaching team to meet the industry development and post technical progress in the school enterprise cooperation business, improve the teaching ability in the process of integrating industrial resources into teaching, and introduce teaching resources into industrial services in the process of off campus parttime and post practice, so as to improve the industrial service ability We should better realize the cooperation between industry, University and research of economic management majors in Colleges and universities, and improve the quality of personnel training.

\section{AUTHORS’ CONTRIBUTIONS}

All the contributions of thesis belong to Zou Dejun.

\section{ACKNOWLEDGMENTS}

Thanks to Jinan University for its literature support.

\section{REFERENCES}

[1] Cheng Long, Cai Junya, Yang Yi, Jia Weifeng. Dependence and Embeddedness: Research on the sustainability of industry university research cooperation innovation [J]. Science and technology progress and countermeasures, 2020,37 (10): 29-36

[2] Hou Xiaohui, Xie Xiang, Huang Lei. Evolutionary game analysis of science and technology input and output quality in industry university research cooperation [J]. Science and technology management research, 2020,40 (02): 130-134

[3] Wang Jiangzhe, Liu Yi, Chen Xiaofei. Industry university research cooperation and transformation of university scientific research achievements: from the perspective of intellectual property protection [J]. Science and technology management research, 2018,38 (17): 119-126

[4] Lin qingfan, Dai Yongwu. Research on the impact of industry university research cooperation policy on the performance of school enterprise technical cooperation $[\mathrm{J}]$. China higher education research, 2017 (12): 71-76

[5] Feng Haiyan. Research on innovation of industry university research cooperation mechanism between universities and enterprises [J]. China higher education research, 2014 (08): 74-78 